\title{
Identification the Role of Urban Planners in Collaborative Planning: A Conceptual Model of Success in Anzali, Iran
}

\author{
Amir Forouhar ${ }^{1}$ and Hanieh Mohammadi ${ }^{2}$ \\ ${ }^{1}$ School of Architecture and Urban Design, Art University of Isfahan, Iran \\ ${ }^{2}$ Faculty of Conservation, Art University of Isfahan, Iran
}

Submission: March 16, 2018; Published: April 06, 2018

*Corresponding author: Amir Forouhar, School of Architecture and Urban Design, Art University of Isfahan, Iran, Tel: +98 93595 19993;

Email: a.forouhar@aui.ac.ir

\begin{abstract}
Nowadays, public participation is one of the most important factors to improve the feasibility, legitimacy and quality of urban plans. In Iran, due to lack of comprehensive understanding about the participation notion and its necessary socio-economic and political infrastructures, participatory decision-making has faced with some serious challenges in both processes of preparing and implementing. This paper focuses on providing practical strategies for preparing collaborative urban plans in Iran's conditions. Also it seeks to answer this question: What is the role of planners to prepare a real collaborative planning? It is presumed that a conceptual model for collaborative planning can be fitted with Iran's conditions by means of integrating the fundamental philosophic ideas of participatory planning such as theories of Paul Michel Foucault and Jürgen Habermas, given the fact that the present collaborative planning in Iran needs a supportive theory which is adopted with power structures in Iranian urban planning system. In this regard the Habermas' theory of "communicative action" and the Foucault's theory of "power structures" are reviewed by a comparative analysis methodology to present an integrated conceptual model for collaborative planning in Iran's condition. At the end, the CDS-making process in the city of Anzali of Iran is analysed to examine this claim in practice. The results yield that enabling urban planners to act as communication facilitators during planning can propel the collaborative planning in Iran from theory to a real practice by means of integrating the positive aspects of communication and power.
\end{abstract}

Keywords: Collaborative Planning; Paul Michel Foucault; Jürgen Habermas; Communicative action; Power; Iran

\section{Introduction}

The concept of participation has long been associated with human life. Currently, public participation has been accepted as an essential factor to good governance in many developed and developing countries. But transferring this concept from Politics to planning scope creates many challenges for planners. In Iran, many arguments have been done about collaborative planning in recent decades. But the results of collaborative plans of Iran show that the concept of participation is understood incorrectly. In fact, the concept of public participation is limited to only people's financial contributions. Therefore, continuing this trend will face the urban plans with many challenges in preparing process (such mismatching between outcomes of plans and real demand of local people) and also in implementation of urban development plans. This paper seeks to present a conceptual model for preparing a real collaborative plan based on Iran's conditions. The main emphasis of this paper is on the role of planners to enhancing communication between local people and planning authorities.

\section{Methods}

The nature of public participation is associated with power and communication. In fact power-based communication is a fundamental factor to achieve a successful collaborative planning; hence we need a comprehensive and applicable approach that covers both "power" and "communication" aspects. For this purpose we peruse the Habermas' theory of "communicative action" and the Foucault's theory of "power" by a Descriptive-Comparative Analysis Methodology. So that, after reviewing the values, strengths and weaknesses of each of these theories, we try to bring them together as a holistic collaborative model according to circumstances of Iran. At the end in order to examine this model in the real circumstances of Iran, the Anzali's experience is explained and analysed. It should be said that there are some studies about the integration theories of Habermas and Foucault [1], But practice this issue in conditions of Iran can be a new study in this field. 


\section{Theoretical Framework: Integration of Communication and Power regarding the Theories of Habermas and Foucault}

In this study to provide a comprehensive model which is applicable in Iran, the Habermas' theory of "communicative action" and the Foucault's theory of "power" are chosen, because it seems that these two ideas can be integrated into a comprehensive model which considers both power structure and effective communication. “Jürgen Habermas' work presents a continuation of the liberal tradition of democracy which became more participatory by Hannah Arendt's viewpoints. Arendt believed that if we have got more people views in mind during the review an issue, our ability will be increased to think on behalf of people, and consequently the final results will be more credible" [1]. "Thereafter, John Forester suggests a critical theory has an important role to play in the praxis of urban planning and public policy-making as it offers a new way of understanding the action of planner (what a planner does) as an attentionshaping (communicative action) rather than more narrowly as a means to some end (instrumental action) [1]. Based on these opinions, Habermas built the model of communicative action. He summarized his ideas of communicative action in an influent phrase: "the conviction that the human social life depends on the various forms of routine communication which is based on the innovation, reciprocity and egalitarianism without any forces" [2]. "The basic premise of Habermas' theory of communicative action is that the participants through inner reflections and interactions with the other minds may find more appropriate perception about the current issue and consequently they may modify their initial preferences to achieve a public result" [3]. In other words, the preferences and attitudes of participants will be propelled to a unit demand during negotiations and communications. "Habermas' theory of communicative action thus postulates that actors be able to distance themselves from their life world, bracket their own particular interests and rationally question their beliefs and assumptions through open discussion" [1]. During such process, subjective questions (such as what is the best thing for me to do?) will be replaced by generalized questions (such as what is the best thing for us to do?) [4]. Furthermore, the theory of Communicative Action teaches us "the outcomes that are negotiated using a participatory decision-making debate with the cooperation of all participants, are consistent with actual needs of local people and also they are accepted more readily by participants than other outcomes which are imposed by the bureaucratic system" [1].

This is very important point for the legitimacy and credibility of urban plans. On the other side, another influential factor to achieve a successful public participation is power. Numerous experiences yield that without considering this factor, many obstacles may emerge in the way of participation. In the scope of urban planning it can be said that traditional understanding of planners about the structure of power has limited opportunities for democratic decision-making. Therefore, it is important to obtain a better understanding about power for identifying the process of participatory decision-making. Definitions of power are manifold and highly diverse. So that, Davis [4] mentions that the power can be good, bad, sinister or ordinary phenomenon. In fact, the power can be associated with oppression and domination forces, or on the contrary it can be a productive and positive force. Thus, it can be said that the power is a relative concept which can transform from a negative force to a positive force according to methodological, epistemological and ethics assumptions. Paul Michel Foucault's [5] work on power to reveal the negative and the positive aspects of power. Concept of Power to Foucault is a general matrix of force relations at a given time, in a given society which may be inhomogeneous and also it can be applied in various ways for different purposes. Foucault puts the negative aspect of power in relation to 'Discipline Concept'. "In his theory, the discipline is a mechanism of control.

Through surveillance, examination and normalization using scientific techniques/ mathematics/ statistics and language, qualified professionals and experts replace coercion of citizens with violence by the gentle force of administration" [1]. He suggests creating the resistance groups against the discipline. In fact, the resistance opposes the ways in which the effects of power are linked with knowledge, competence and qualifications and struggle against the privileges of knowledge. He highlights that if the resistance group is created against negative aspect of power, the positive aspect of power can be transferred to the local people. "Such positive kind of power invites people to speak, assess and express their views" [1]. So, the power notion to Foucault is a positive and productive force which can be used to execute the real public participation during planning.

Regarding above discussion, it can be concluded that there are some similarities and complementarity between participatory theories of Jürgen Habermas and Michel Foucault. "One of the major similarities is emphasizing on the "Communication" notion in Habermas' Theory and "Discourse" concept in Foucault's theory as the unique principle for participatory decision-making. On the other hand, Habermas and Foucault both regard power as being a negative force while comes from the knowledge or situation of experts and authorities (Scientific-Technical Rationality in Habermas' idea and Discipline notion to Foucault), because it can lead to ignore the local people in the planning process. To avoid it, Habermas suggests the communicative rationality and Foucault suggests the resistance groups. "In fact, both authors demonstrate power as a negative force, through domination and oppression, but also a positive and liberator force. Also, both believe the importance of language, communication and mutual relationship in conferring power.

"In theory of power, Foucaultsuggests the localized resistance, but he does not provide any practical strategies or any guidelines for the changes should be made. Also he just focuses on the resistance to power and leaves the problem of power unsolved" [6]. On the other hand, "Habermas' theory of communicative 
action is also inadequate as a general paradigmatic model for decision-making" [1]. Although this theory is normative, but it is abstracted from the real world; as Habermas himself admits, it purports to describe the ideal behaviours rather than actual behaviours and such ideal behaviours are separate from power structures [7]. In addition, conditions of real speech often are not matched with the ideal speech situation of Habermas' theory. As Alexander explained, the theory of communication of action cannot become a holistic paradigm for planning and decisionmaking because it covers only a limited part of the universe of actions and interactions [1].

Therefore in this study, we have got two partial frameworks: one analytical, the other normative; one substantive, the other procedural. In fact, each part can only reveal to us an incomplete aspect of public participation. So in order to elaborate a comprehensive model, we believe that the two ideas are complementary and there is a need for a new model of policy decision-making which include both concepts of power and communication.

\section{Collaborative Planning in Iran}

Despite the necessity of citizen participation in urban planning and city development, Iran has not a long experience in this issue. On the other hand, due lack of necessary legal and institutional infrastructures to prepare and implement participatory plans, public participation in Iran has been faced with many difficulties and obstacles and the role of citizens in city development affairs is very poor and negligible. Review and assessment of the Iran's collaborative planning experiences show that these plans have been prepared and implemented without any regards to fundamental principles of public participation and they have got just a beautiful title "collaborative planning". "In fact, public participation in such plans is a kind of tokenism, because the participation has been considered as a remedy for financial problems and also for giving false legitimacy to such plans" [8]. Also in some cases the private sector investments have been considered as public participation, it demonstrates the misunderstanding about the public participation concept in Iran.

Consequently, failure to meet the expected demand of local people during such plans, have caused the citizens and local people to lose their trust to such plans and they also remain deeply pessimistic about to planning and urban management authorities. In addition, political obstacles as lack of sufficient tendencies to accept the public participation costs have caused failure to prepare and implement the real collaborative plans in Iran. "Although, there are rare experiences that closed to real collaborative planning such as enabling plan of Zahedan City of Iran (SHIR-ABAD Neighbourhood). These experiences show us the collaborative planning in Iran's conditions is possible and reachable with intelligent planning and real tendencies of authorities to participate the local people in planning" [8].

\section{Conceptual Model for Collaborative Planning with Emphasis on the Role of Urban Planners}

The conceptual model of this study is driven from the principles and participatory theories were mentioned and also based on the Iran's conditions in the socio-cultural, legal and political contexts. This model focuses on enabling and empowering the urban planners and also local people during the process of preparing the collaborative plans. In this model the planners should improve their abilities to consider the power structures during the process of planning as well as to establish the effective relationships and communications between key actors. This model is based on creating equal opportunities for participants to declare their ideas about decisions, strategies and policies of development plans through respect to their identities, values and needs. On the other hand, this model must recognize the existing power structures and relations of participants and also it should consider this fact that some persons and groups are in better positions to speak politically, economically and psychologically, meanwhile providing fundamental infrastructures to establish an effective communication between the participants. "Habermas and Foucault both regard power as being a negative force, through domination and oppression, but also a positive force" [1].

Actually, they believed that the exercise of power is not just a top-down or a repressive force, it also productive, enabling and positive. So such Studies should be able to cover the both dimensions of power; one as a restrictive factor and other as a productive [4]. It can be said that the exercise of power consists to steer the behaviours of others with various methods and different ways. Suffice it to highlight the applicability to planning practice. Hillier [1] emphasizes that for planning, structuring the possible field of action of others involves more than simply intervening to prevent an action and includes restructuring the type of action open to a person by restricting what they can do. In fact, "planning should govern conducts by modifying people's understanding of the alternatives from which they must choose" [9].

Clearly, it can be done through improving perceptions and analytical skills of local people about the present situation of their environments. So, the model strategy is the acquisition of knowledge for the local people to gain the productive power. Such transfer of power to the local people enhances the abilities of local people and citizens to declare their opinions, views and comments more effective and more efficient during decision-making process. This transferring of power and also improving the local people's knowledge and understanding is a momentous duty for urban planners during preparing collaborative plans. On the other side, this duty can be done by means of communications, negotiations and holding meetings. The establishment process of such communications requires a comprehensive understanding about the power structures and also the ways which participants use it to exercise their power. 
Therefore, the planner's ability to act as a communication facilitator is the most fundamental prerequisite to achieve a successful collaborative planning. In other words, planner should change his (her) role from an elite to a facilitator to provide the power/knowledge for local people and consequently to establish the communications between local people and planning authorities. This new role of urban planners can be considered as an important step toward integration the positive aspects of power and communication in the process of collaborative planning based on participatory theories of Foucault and Habermas and also the Iran's conditions.

\section{Main Components of the Conceptual Model and their Functions within a System}

Table 1: Main Components of the Conceptual Model (Key Actors).
Hillier [1] summarizes her idea about collaborative planning in a simple but meaningful phrase: "The democratic planning is a process of decision-making that is open to all participants and their views, opinions and comments and the decisions resulting from this process will be legitimate if they are reflected from the mutual understanding, respect and cooperation." In order to achieve such democratic planning, four main components as the key actors have been considered in the this model: Local people and planning authorities as the main sides of the negotiation process with the various, different and opposite views and needs; Urban planners as communication facilitators and Intermediary organizations as overseers and supervisors of the project (Table 1).

\begin{tabular}{|c|c|c|}
\hline Key Actors & Characteristics & Rights And Duties \\
\hline \multirow{7}{*}{ Citizens and Local People } & \multirow{7}{*}{$\begin{array}{l}\text { They are the real wealth of plans and the main } \\
\text { objects of the urban planning process. }\end{array}$} & $\begin{array}{l}\text { a) Prioritize the public interests over the personal } \\
\text { interests. }\end{array}$ \\
\hline & & b) Play an active role in the negotiations. \\
\hline & & $\begin{array}{l}\text { c) Respect and listen to all opinions (although } \\
\text { different). }\end{array}$ \\
\hline & & d) Respect to the mutual rights. \\
\hline & & Serious consideration to the public benefits. \\
\hline & & $\begin{array}{l}\text { f) Do not criticize without offering beneficent } \\
\text { suggestions. }\end{array}$ \\
\hline & & g) Trust to the participation process. \\
\hline \multirow{5}{*}{ Planning Authorities } & \multirow{5}{*}{$\begin{array}{l}\text { They have got the power to make decisions } \\
\text { inherently and also they have appropriate } \\
\text { access to resources and information. }\end{array}$} & a) Provide prerequisites for the public participation. \\
\hline & & b) Accept the costs of public participation. \\
\hline & & $\begin{array}{l}\text { c) Facilitate the establishing of local councils, NGOs, } \\
\text { CBOs and voluntary organizations. }\end{array}$ \\
\hline & & $\begin{array}{l}\text { d) Prioritise the public interests over the specific and } \\
\text { personal interests of powerful or elite class. }\end{array}$ \\
\hline & & $\begin{array}{l}\text { e) Facilitate the process of transferring power to local } \\
\text { people. }\end{array}$ \\
\hline \multirow{10}{*}{ Urban Planners } & \multirow{10}{*}{$\begin{array}{l}\text { They act as a communication facilitator and } \\
\text { they have got the power and knowledge to } \\
\text { influence on the local people and the planning } \\
\text { authorities. }\end{array}$} & $\begin{array}{l}\text { a) Enhance the capacity of people to define their } \\
\text { problems and demands. }\end{array}$ \\
\hline & & $\begin{array}{l}\text { b) Use their power and knowledge to protect the rights } \\
\text { of local people as a lawyer and advocate of local people. }\end{array}$ \\
\hline & & c) Extract the real interests and needs of local people. \\
\hline & & $\begin{array}{l}\text { d) Transfer the positive aspects of power and } \\
\text { knowledge to local people. }\end{array}$ \\
\hline & & e) Act as a facilitator in communication process. \\
\hline & & $\begin{array}{l}\text { f) Honest endeavour to consider the real views and } \\
\text { needs of local people rather than just a fake action to } \\
\text { silence the protests. }\end{array}$ \\
\hline & & $\begin{array}{l}\text { g) Identify stakeholders, participants, power-holders } \\
\text { and their interests. }\end{array}$ \\
\hline & & h) Identify hidden structures of power. \\
\hline & & $\begin{array}{l}\text { i) Turn power from a negative force to a productive } \\
\text { and positive force. }\end{array}$ \\
\hline & & $\begin{array}{l}\text { j) Provide appropriate conditions for local people } \\
\text { to monitor the process of preparing and implementing } \\
\text { plans. }\end{array}$ \\
\hline
\end{tabular}




\begin{tabular}{|c|c|c|}
\hline \multirow{5}{*}{ Intermediary Organizations } & \multirow{5}{*}{$\begin{array}{l}\text { They consist local doyens, confidantes and } \\
\text { relevant experts who have been qualified by } \\
\text { the negotiators }\end{array}$} & $\begin{array}{l}\text { a) Build a relationship between planners and local } \\
\text { people }\end{array}$ \\
\hline & & $\begin{array}{l}\text { b) Prevent deterioration of balance in the negotiations } \\
\text { due power and ability of certain people. }\end{array}$ \\
\hline & & $\begin{array}{l}\text { c) Push the negotiations toward more equality and } \\
\text { justice. }\end{array}$ \\
\hline & & $\begin{array}{l}\text { d) Prevent domination by certain people in the } \\
\text { negotiation process. }\end{array}$ \\
\hline & & $\begin{array}{l}\text { e) Stand against pressure from organized groups } \\
\text { (including planners and professionals, and power- } \\
\text { holders). }\end{array}$ \\
\hline
\end{tabular}

Another important point about this issue is the fact that the detailed process of collaborative planning depends on the specific circumstances of each plan, so the conceptual model of this study should be a strategic model and the action policies at the micro-scale will be designed based on the specific socioeconomic, cultural and political environments of each plan. The conceptual model for collaborative planning based on integration the positive aspects of power and communication is shown in Figure 1. We believe that this model is applicable in the real life world and also it certainly facilitates the process of implementing such plans, because "in a fair decision-making process the participants recognize the need to subordinate some immediate desires for the sake of cooperation. In fact, People basically seek to maximize their personal benefits, but when they understand that the better outcomes are achieved through cooperation with others, they will ready to put aside the personal interests and act to help all members of the group. One of such cooperative acts is the accepting outcomes and procedures which are based on the fairness rather than just their personal interests" [10]. As a result, the decisions and policies are derived from the fair process will be approved by participants despite the fact that the results may be opposite to their personal interests and benefits [1]. It should be noted that the full consensus in a decision is often impossible, but generally, the negotiated agreements have got the theoretical advantages compared with the non-democratic decisions taken by professionals and elites. Furthermore the implementation of such plans after the preparation process requires certain preconditions in Iran. These conditions can be provided by changes in social- cultural and administrative structures.

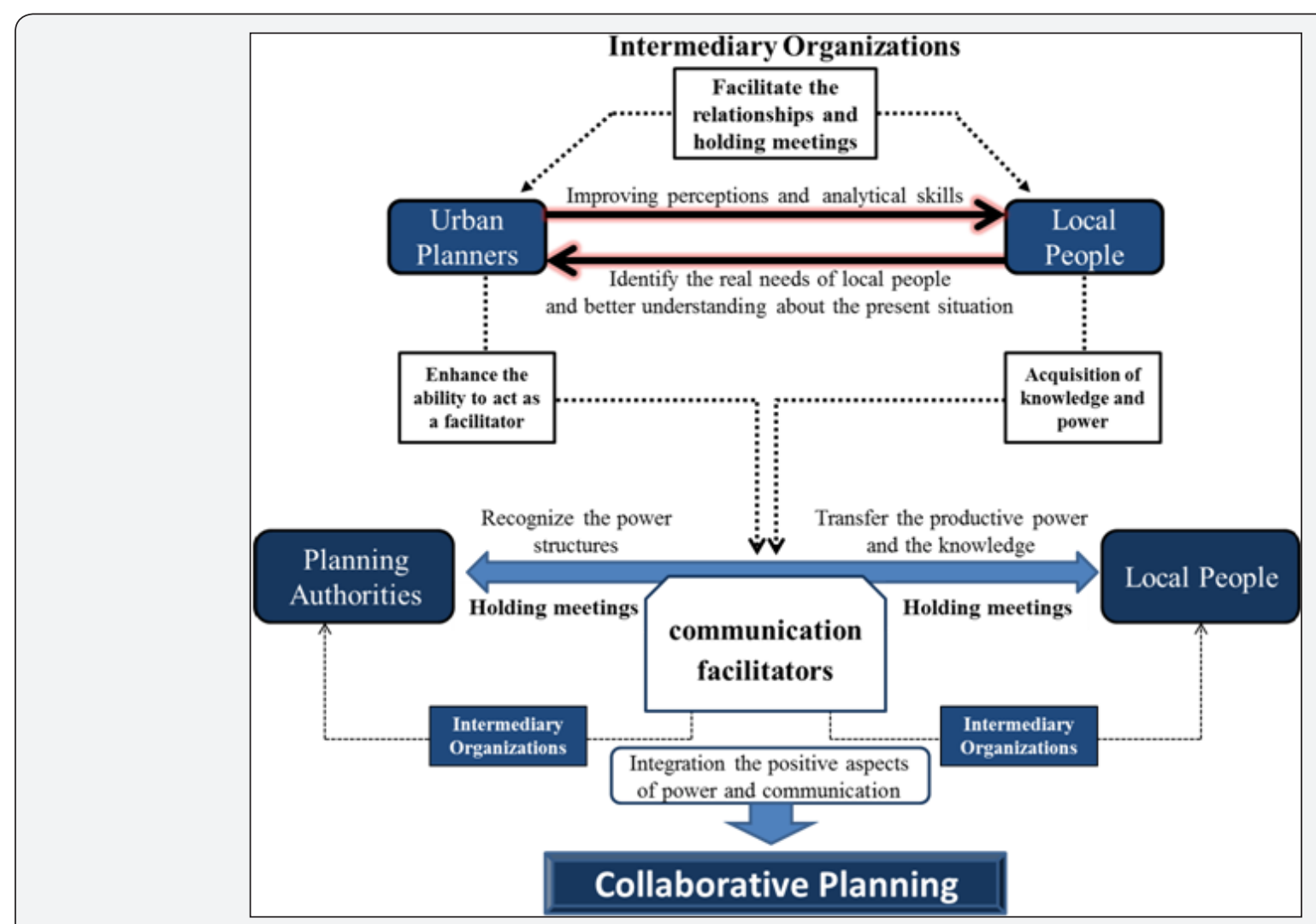

Figure 1: Conceptual Model for Collaborative Planning with Emphasis on the Role of Urban Planners. 
Case study: City Development Strategy (CDS) of Anzali, Iran: Processes and Challenges

In this section to illustrate the implementing process of the present conceptual model under the circumstances of Iran and also to provide guidelines and action policies in microscale, participatory process of decision-making during the city development strategy (CDS) of Anzali in Iran will be reviewed. It is presumed that the process of Anzali's CDS executed the idea of present paper in the real conditions of Iran within the acceptable quality range and subsequently it closed in many respects to the real collaborative planning. In fact this section is conducted to examine the feasibility of the conceptual model in Iran's planning system. Furthermore, it can indicate the challenges that may happen during implementation of this conceptual model in Iran's conditions.

City development strategy is one of the key approaches that is proposed by Cities Alliance in 1999 as an action-oriented process, developed and sustained through participation, to promote equitable growth in cities based on a long-term perspective and short-term policies to improve the quality of life for all citizens $[11,12]$. The CDS approach is based on three important principles of enablement, participation and capacity building. Empowering local authorities, local communities, stakeholders and other partner and beneficiaries is a necessary condition for the CDS exercise. In fact without the participation of those at the local level, sustainable citywide strategies cannot be achieved. This participation must be genuine, resulting in local ownership of the process. For that participation to be meaningful, civil society organizations and city government institutions need solid institutional and technical capacity [12].
The CDS approach emphasises on the formation of working groups, workshops and consultative meetings attended by local people, key actors and local authorities and also all stakeholders and beneficiaries to prepare the high-quality strategic plans based on the real demand of communities [13]. In recent years subsequent to revealing the defects of traditional master plans in Iran, the preparation of City Development Strategies was centered on the Iran's planning system under a grant from the Cities Alliance. For this purpose three cities had been selected as pilot bases (Qzvin, Anzali and Shahroud).

Bandar-e-Anzali (English: Anzali Port) is the capital city of Anzali County, Gilan Province with about 110000 population covers an area about 250 square kilometers (Figure 2). Bandar-e Anzali (Anzali Port, "Bandar" means "port") is one of the most densely populated harbor towns on the Caspian Sea and it plays an important role in the north of Iran especially in economic and tourism terms. Also it has a significant importance on international level as the largest modern seaport adjacent to the Caspian Sea. Actually due to the location advantages, Anzali City has significant opportunities for developing such as international cargo transit services and facilities, tourist attractions (Anzali Wetland, coast of Caspian Sea, pristine forests), appropriate accessibility to oil and gas resources of the Caspian Sea and scarce opportunity for fishing industry (the world capital of precious caviar), so that this city became to Special Economic Zone (SEZ) and Industrial/Commercial Free Zone (ICFZ) form 2003. But during the last decades this city has faced with many challenges due to inefficient and non-participatory urban plans that are often implemented partially. Some important weaknesses of Bandar-e-Anzali are:

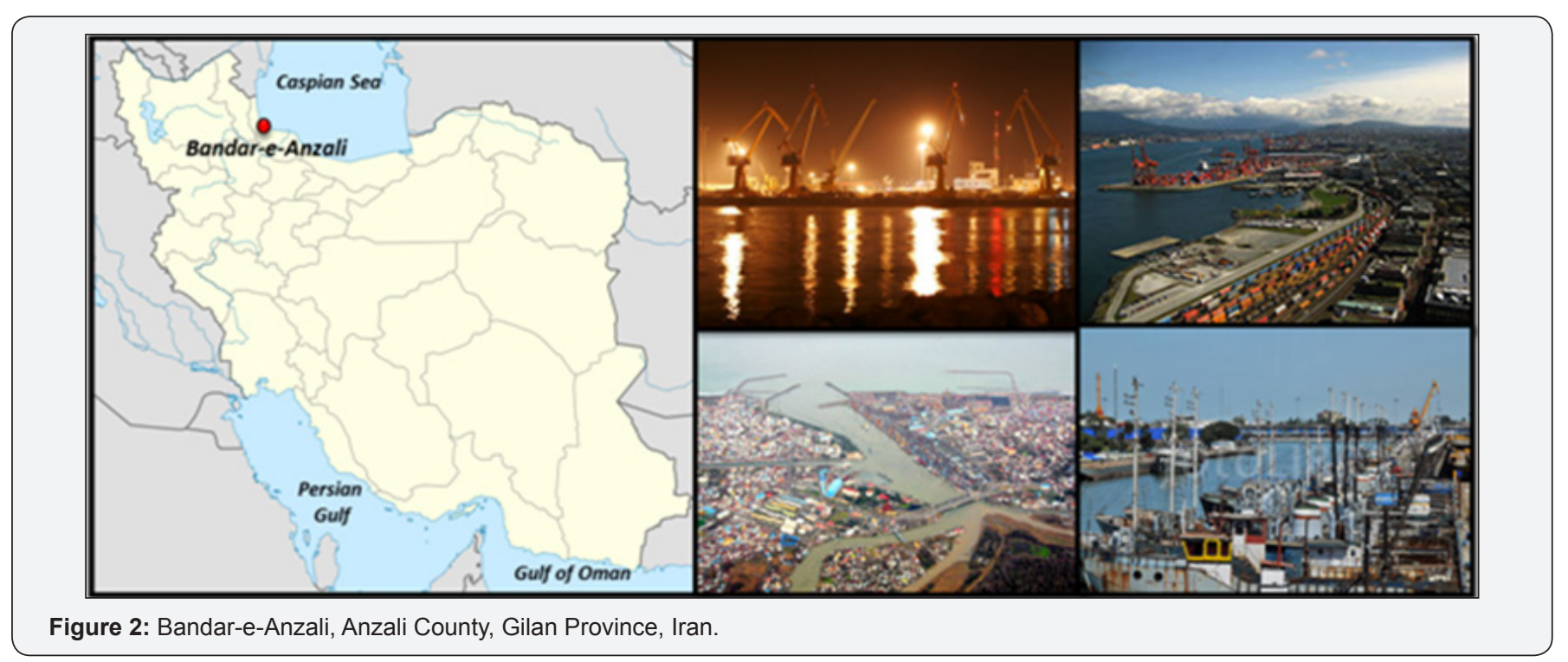

a) Degradation of capital vibrancy and investment interest

b) Lack of basic infrastructures to develop the tourism industry c) Overall limits of the city development due to surrounded by sea and wetland

d) Superlinear growth of the city and its consequent problems for connecting different parts of the city 
e) Deterioration of the quality of old textures

f) Environmental pollutions Including groundwater, wetland and Caspian sea

g) Lack of integrated urban management

To overcome mentioned challenges and also to promote sustainable development in Bandar-e Anzali the following process has been considered for preparation the Anzali CDS: [14]

a) Preliminary stage includes introducing the CDS plan and the organization of working groups.

b) Reviewing the previous master plans and also planning for holding the meetings with NGOs, CBOs, citizens, stakeholders, developers and planning authorities.

c) Identification of present situation of Anzali City in economic, sustainable development, urban poverty and urban infrastructure contexts.

d) Data analysis and preparation of the draft vision.

e) Assessment of the proposed visions and Select the ultimate vision for the city.

f) Preparation of the city development plan, strategies, policies and action plans.

g) Assessment of the results and set up a national seminar about CDS.

As can be seen in this process, five stages (from $b$ to $g$ ) have the potential for public participation. So two major stages and four sub-stages have been considered in this process for public

Table 2: Public Participation Process in the Anzali CDS [14]. participation according to the process of preparing the Anzali CDS. At the beginning in order to participate all stakeholders and beneficiaries in decision-making process, working groups were formed with different duties and various purposes based on four main sections of the study (Economic Development, Urban Poverty, Urban environment and Financial Sustainability) [14]. These working groups embrace the wide range of associated official organisations, NGOs, CBOs, local leaders, doyens, confidantes, voluntary organizations, urban professionals, relevant experts and also citizens and local people who are interested in participating. The main task of these working groups was identifying the present situation of Anazly city and the real needs of citizens by means of cooperation with local people [14]. Also they aimed to transfer the knowledge/power to local people by holding the intergroup meetings. So these working groups not only improve the planners' understanding about the real situation of the city, but also it can enhance the analytical skills of local people to gain productive power.

In fact by means of this policy the effective and empowering communication can be achieved between planners and local communities. Furthermore, in the process of Anzali CDS two public assemblies were considered by planners to conduct a comprehensive participatory decision-making. These essential assemblies should be attended by all citizens, key actors and planning authorities. The first assembly aimed to introduce the City Development Strategy and also to enhance the enthusiasm of local people for participating in this process and the second assembly was considered to announce the final results and also to realize the feedbacks of citizens and stakeholders at the final stage of planning. The details of conducted procedure are shown in Table 2.

\begin{tabular}{|c|c|c|c|}
\hline Stage of participation & Target of participation & Brief Description & No of Meetings \\
\hline \multirow{5}{*}{$\begin{array}{l}\text { Participation in the primary } \\
\text { Stage }\end{array}$} & \multirow{5}{*}{$\begin{array}{l}\text { Providing Preliminary } \\
\text { Requirements for } \\
\text { preparing the CDS Plan }\end{array}$} & $\begin{array}{l}\text { a) Identification of key actors, NGOs, CBOs } \\
\text { and the main stakeholders. }\end{array}$ & \multirow{5}{*}{30} \\
\hline & & $\begin{array}{l}\text { b) Organization of meetings with the } \\
\text { key actors, NGOs and CBOs, the main } \\
\text { stakeholders and the planning authorities. }\end{array}$ & \\
\hline & & $\begin{array}{l}\text { Organization of technical working } \\
\text { groups in economic, sustainable } \\
\text { development, urban poverty and urban } \\
\text { infrastructure scopes. }\end{array}$ & \\
\hline & & $\begin{array}{l}\text { d) Define aims and the process of } \\
\text { preparing plan based on participants' views. }\end{array}$ & \\
\hline & & $\begin{array}{l}\text { e) Reviewing the previous master plans } \\
\text { and schemes. }\end{array}$ & \\
\hline & \multirow{3}{*}{$\begin{array}{l}\text { Identification of present } \\
\text { situation of Anzali and the } \\
\text { real needs of local people }\end{array}$} & $\begin{array}{l}\text { a) Introduction and training of the leaders } \\
\text { of working groups. }\end{array}$ & \multirow{3}{*}{64} \\
\hline & & $\begin{array}{l}\text { b) Holding meetings with the working } \\
\text { groups. }\end{array}$ & \\
\hline & & $\begin{array}{l}\text { c) Synchronization of working groups and } \\
\text { Comprehensive understanding of present } \\
\text { situation of Anzali City. }\end{array}$ & \\
\hline
\end{tabular}




\begin{tabular}{|c|c|c|c|}
\hline \multirow{3}{*}{$\begin{array}{l}\text { Participation in the Final } \\
\text { Stage }\end{array}$} & \multirow{3}{*}{$\begin{array}{l}\text { Data analysis and } \\
\text { preparing proposed } \\
\text { visions for the city }\end{array}$} & a) Introduction the analytical models. & \multirow{3}{*}{22} \\
\hline & & $\begin{array}{l}\text { b) Holding meetings with technical } \\
\text { working groups, officials and authorities to } \\
\text { prepare the holistic draft SWOT. }\end{array}$ & \\
\hline & & $\begin{array}{l}\text { c) Providing the draft visions for the } \\
\text { city based on the draft SWOT and also the } \\
\text { information of previous stages. }\end{array}$ & \\
\hline & \multirow{3}{*}{$\begin{array}{l}\text { Providing the ultimate } \\
\text { vision and the city } \\
\text { development strategy }\end{array}$} & $\begin{array}{l}\text { a) Assessment of the proposed visions by } \\
\text { holding the public assembly for all citizens, } \\
\text { stakeholders, key actors, NGOs and CBOs, and } \\
\text { the planning authorities. }\end{array}$ & \multirow{3}{*}{15} \\
\hline & & b) Select the ultimate vision for Anzali City. & \\
\hline & & $\begin{array}{l}\text { c) Provide strategies, policies and action } \\
\text { plans by means of holding the meetings with } \\
\text { all participants. }\end{array}$ & \\
\hline
\end{tabular}

Moreover, three workshops at the urban-level were held by planners to enhance knowledge/power and comprehension skills of citizens and local communities in co-operation with working groups at the beginning, middle and final points of the planning process. The first workshop was held at the third stage of the planning process of Anzali CDS to identify the present situation of Anzali City, the second at the fourth stage to data analysis and prepare a draft vision and the final workshop was held at the sixth stage to prepare a city development strategy. These workshops were very helpful for planners to gain a comprehensive understanding about the facts, real needs, problems and views of local people, stakeholders and key actors. Also besides holding the mentioned meetings, some informal meetings and interviews were organised such as meetings with local authorities of urban council, official organizations and government departments of Anzali City, and also with relevant experts of previous master and detailed plans of Anzali City. Such meetings play a significant role to provide the prerequisites for preparing the CDS plan [14].

In contrast, some structural defects are also seen in the preparing process of Anzali CDS. For example the planners decided that the first public assembly not be held; because not only they were worried about unexpected feedbacks of citizens and developers, but also due changes in management structures, the local government was not ready to hold it perfectly. So they limited the first public assembly to a notification at the meetings of technical working groups. Also the national seminar at the final stage was not held despite the keen interest of planners. The planners believe that some reasons for such failures in the preparing process of Anzali CDS are:

a) Lack of sufficient knowledge about the preparing process of CDS due to being new for all persons who involved in this process

b) Failure to provide the sufficient macro-level infrastructures in the legal, socio-cultural and political contexts

c) Failure to provide the facilities needed at the local level such as workplaces, human resources and legal support

\section{d) Difficulty in accessing to information and statistics}

Regarding to the mentioned procedure of preparing the Anzali CDS, it can be stated that this participatory decisionmaking was closed in many respects to the real collaborative planning by means of intelligent acting of urban planners. In fact during this process, planer tried honestly to change his/her role to establish the bilateral relationships between authorities and local people and also to identify real facts and needs of citizens. On the other hand, planners sought to enhance the knowledge/power of local people by organizing working groups and holding technical meetings. Consequently, local people gained the productive power to participate efficiently during the planning process. On the other side, planners believed that the consideration of power is a critical factor to achieve a successful collaborative planning, so that they sought to involve the local leaders, key actors, investors and also the planning authorities from the beginning of the process. In addition, involving NGOs, CBOs and voluntary organizations during the preparing process of Anzali CDS was a useful strategy to attract citizens' trust and also to improve the sense of justice and fairness for local people during the decision-making process. As a result, the participatory decision-making during the Anzali CDS can be a useful guideline to implement the conceptual model of present study for collaborative planning in Iran's conditions.

\section{Conclusion}

The base belief of this study is that the local planning cannot be understood separately from the social structures, native identities and local people's meanings and values. So, in this paper, to identify the key factors for achieving a real collaborative planning based on Iran's conditions the Habermas' theory of communicative action and the Foucault's theory of power are examined. The results yield that the integration of these important theories into a holistic approach can produce a conceptual model for collaborative planning which considers both notions of effective communication and power structure.

In the proposed model, urban planner plays a key role to implement the model successfully. In fact, the planner should change his/her role from elite to a facilitator who has an 
obligation to establish a bilateral relationship between local people and planning authorities. This obligation can be done by the acquisition of the positive aspects of knowledge/power for local people and also by a comprehensive recognizing about the power structures. Consequently, urban planners can facilitate the communication between local people and authorities to prepare plans based on the consensus of all opinions, views and needs of key actors. Also the model emphasizes on involving Intermediary Organizations Such as local councils, local leaders, NGOs, CBOs as a useful method to facilitate the public participation during planning.

On the other hand, reviewing the participatory decisionmaking in the Anzali CDS shows that real collaborative planning in Iran is not just a dream, but also by means of an intelligent act of planer, both citizens and authorities can consulate at the negotiation table. During this process planers tried honestly to involve the key actors of model (local people, planning authorities, NGOs) to prepare a successful collaborative plan based on the real demands of local people and opinions of the key actors. Therefore, decisions and policies are derived from such fairly process will be approved by participants and subsequently it can enhance the legitimacy and the feasibility of urban plans in Iran at the execute phase.

Thus, the important point after preparing the collaborative plans is providing the necessary preconditions for implementing such plans. In fact, inattention to these preconditions can lead to failure at the execute phase and consequently it makes citizens hopeless and deeply pessimistic to participate in such plans. So one of the ways to continue this research is answering this question: What kinds of changes need to be made in economic and social- cultural contexts and also in administrative regulations to implement the collaborative plans successfully in Iran?

\section{References}

1. Habermas Jürgen (1985) the Theory of Communicative Action. 2 vols Beacon Press.

2. Habermas Jürgen (1986) Autonomy and Solidarity. London: verso, UK.

3. (2000) Clare a, Language and Disclosure: Habermas and the Struggle for Reason in P Corcoran and V Spencer (edn.); Disclosures, Alder shot Ashgate.

4. Davis, Kathy (2002) Critical Sociology and Gender Relations. Manchester: Manchester University Press, England.

5. Foucault Michel (1982) the Subject and Power 8(4): 777-795.

6. Honneth A (1991) the Critique of Power. Cambridge: MIT press, USA.

7. Ashenden S, Owen D (1999) Foucault contra Habermas: Recasting the Dialogue between Genealogy and Critical Theory. London: SAGE Publications Ltd, UK.

8. Saeedi Rezvani H (2006) Implementing Collaborative Planning in Irans Conditions. Art Journal of Tehran, University of Tehran.

9. Allen B (1998) Foucault and Modern Political Philosophies. The Later Foucault, London: Sage, UK.

10. Jerry M, Souls LW (2000) Handbook of Social Comparison: Theory and Research. Kluwer Academic, Plenum Publishers, USA.

11. Cities Alliance.

12. Un-Habitat for a better Future.

13. Norris PA (2000) Virtuous Circle: Political Communications in Post Industrial Societies. Cambridge University Press, New York, USA.

14. (2009) The Ministry of Housing \& Urban Development of Iran, City Development Strategy (CDS) of Anzali City, Iran Center of Urban and Architecture Researches (ICUAR).

\section{Your next submission with Juniper Publishers will reach you the below assets}

- Quality Editorial service

- Swift Peer Review

- Reprints availability

- E-prints Service

- Manuscript Podcast for convenient understanding

- Global attainment for your research

- Manuscript accessibility in different formats

( Pdf, E-pub, Full Text, Audio)

- Unceasing customer service

Track the below URL for one-step submission https://juniperpublishers.com/online-submission.php 